\title{
The Mosaic with Family Portraits and Mythological Figures in the Villa Armira near Ivailovgrad, Bulgaria
}

\author{
Ivailovgrad, Bulgaristan Yakınlarındaki Villa Armira'da Aile Portreleri ve \\ Mitolojik Figürler İçeren Mozaik
}

David PARRISH*

(Received 14 January 2020, accepted after revision 06 August 2020)

\begin{abstract}
This article draws inspiration from Jean-Pierre Darmon's belief that the figural mosaics decorating Roman private homes often have an educational function, serving as a form of paideia and representing cherished social and cultural values of the classical tradition. That notion is applied to a mosaic embellishing the Villa Armira located near Ivailovgrad in southeastern Thrace (modern Bulgaria) and dated to the $2^{\text {nd }}$ century AD. The pavement depicts very lifelike portraits of three family members in addition to numerous mythological subjects. The latter helped inform the children represented about important social and moral concepts reflected in the mosaic imagery, thereby preparing them for future adult life. Besides making a detailed description of the pavement in question, the article draws comparisons with mosaics from other imperial Roman provinces. This pavement is an outstanding example of the assimilation of Greco-Roman culture in the region of Thrace during the High Empire.
\end{abstract}

Keywords: Villa Armira, Thrace, Ivailovgrad, portraits, paideia.

\section{Öz}

Bu makale, Jean-Pierre Darmon'un Roma özel evlerini süsleyen figüral mozaiklerin genellikle bir eğitim işlevi gördüğü, bir paideia (okul) görevi gören ve klasik geleneğin kiymetli sosyal ve kültürel değerlerini temsil ettiği inancından ilham almaktadır. Bu düşünce, Trakya'nın güneyinde (modern Bulgaristan) Ivailovgrad yakınlarında bulunan ve IS 2. yüzyıla tarihlenen Villa Armira'yı süsleyen bir mozaiğe uygulanmaktadır. Döşemede çok sayıda mitolojik konuya ek olarak üç aile üyesinin çok gerçekçi portreleri gösterilmektedir. Mitolojik öğeler mozaik görüntülerinde yansitılan önemli sosyal ve ahlaki kavramlar hakkında temsil edilen konular ile çocukları bilgilendirmeye yardımcı oluyordu ve böylece onları gelecekteki yetişkin yaşamına hazırliyordu. Makale, söz konusu döşemenin ayrıntılı bir tanımını yapmanın yanı sıra, diğer Roma İmparatorluğu eyaletlerinden gelen mozaiklerle karşılaştırmalar yapmaktadır. Bu mozaik, Yüksek İmparatorluk Dönemi'nde Trakya Bölgesi'nde Greko-Romen kültürünün asimilasyonunun olağanüstü bir örneğidir.

Anahtar Kelimeler: Villa Armira, Trakya, Ivailovgrad, portreler, paideia.

\footnotetext{
* David Parrish, School of Design, Art, and Performance, Purdue University, West Lafayette, Indiana, USA. (D) https://orcid.org/0000-0003-4076362X. E-mail: dparrish@purdue.edu
} 


\section{Introduction}

This article pays tribute to one aspect of Jean-Pierre Darmon's pioneering research in ancient Roman mosaics, namely, his belief that mosaic imagery often served an educational purpose and was a form of paideia in Roman private households (Balmelle - Darmon 2017: 174-178, 319-327; Darmon 2018: 178179, 368-369). The pavement example discussed here (Figs. 1 - 2) is the mosaic decorating Room 10 (Mladenova 1983: 153-156 figs. 8-10; Mladenova 1991: 24, 36, 157; Dunbabin 1999: 321 fig. 317; Kabakchieva 2012: 33 figs. on 32-35; Popova 2015: 577-579 fig. 1; Valeva 2015: 447) in the Villa Armira ${ }^{1}$ in southern Thrace, situated $4 \mathrm{~km} \mathrm{SW}$ of the town of Ivailovgrad in modern Bulgaria (for a map locating the site, see Mladenova 1983: 150 fig. 1). This luxurious villa formed part of a large estate and contains both a pars urbana and a pars rustica. The quite well preserved pavement, discovered in 1964 by Janka Mladenova of the Archaeological Institute and Museum of the Bulgarian Academy of Sciences, occurs in situ and is dated to the second quarter of the $2^{\text {nd }}$ century AD. It has dimensions of $7.60 \mathrm{~m} \times 5.40 \mathrm{~m}$ and is oriented toward the $\mathrm{N}$ end of Room 10, a space seemingly reserved for family use (Fig. 3). Room 10 occurs immediately above the NW corner of the peristyle in the villa plan.
Figure 1

Overall view of mosaic in Room 10, looking S. Photo courtesy of V. Popova.

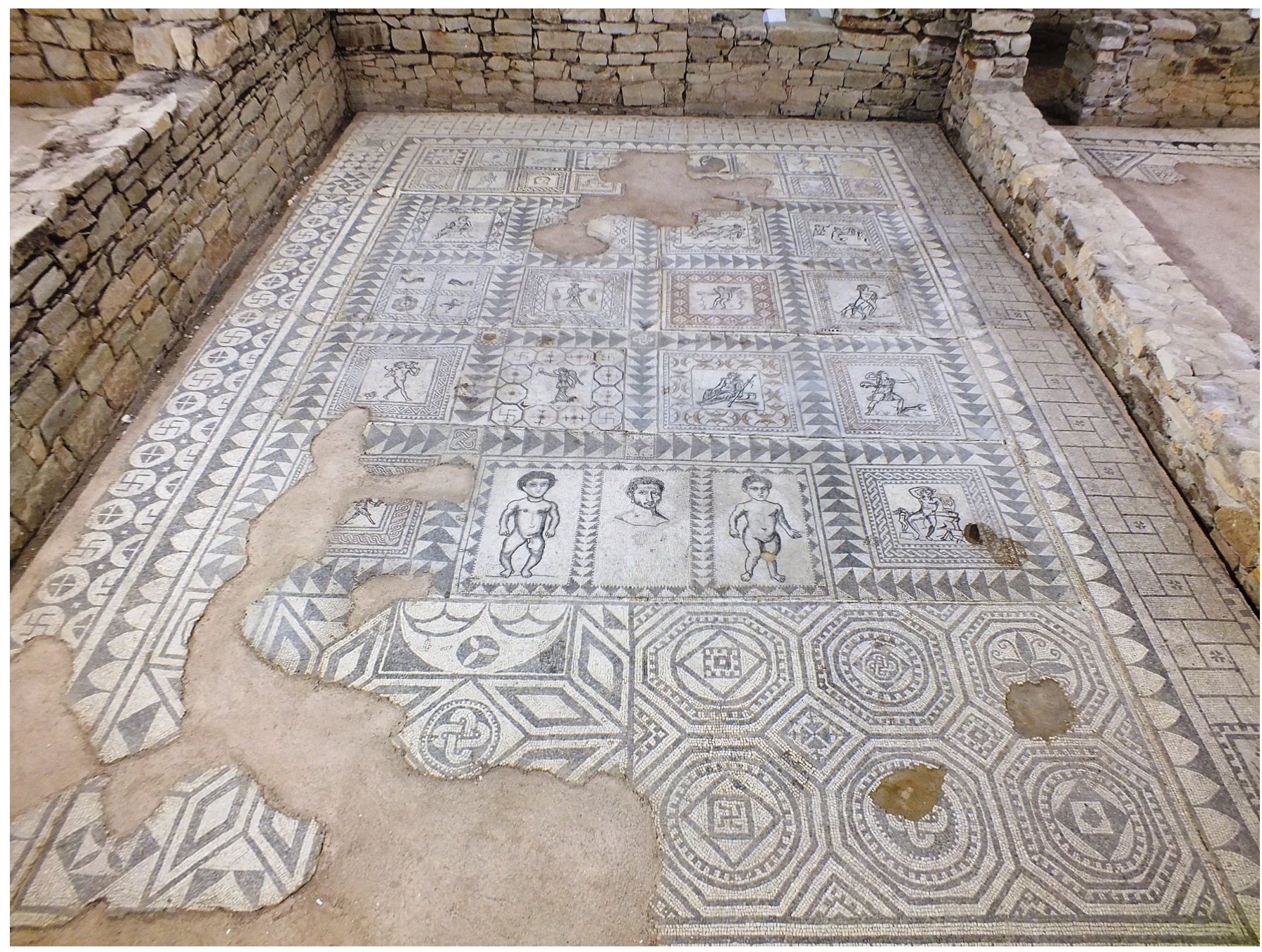

1 On the villa's architecture and sculptural decoration, see Mladenova 1991: 136-137, 139-140, 191194 (English summary of Bulgarian text); Kabakchieva 2011: villa plan, fig. 2; Kabakchieva 2012: 1-40, villa plan, fig. on 13. 


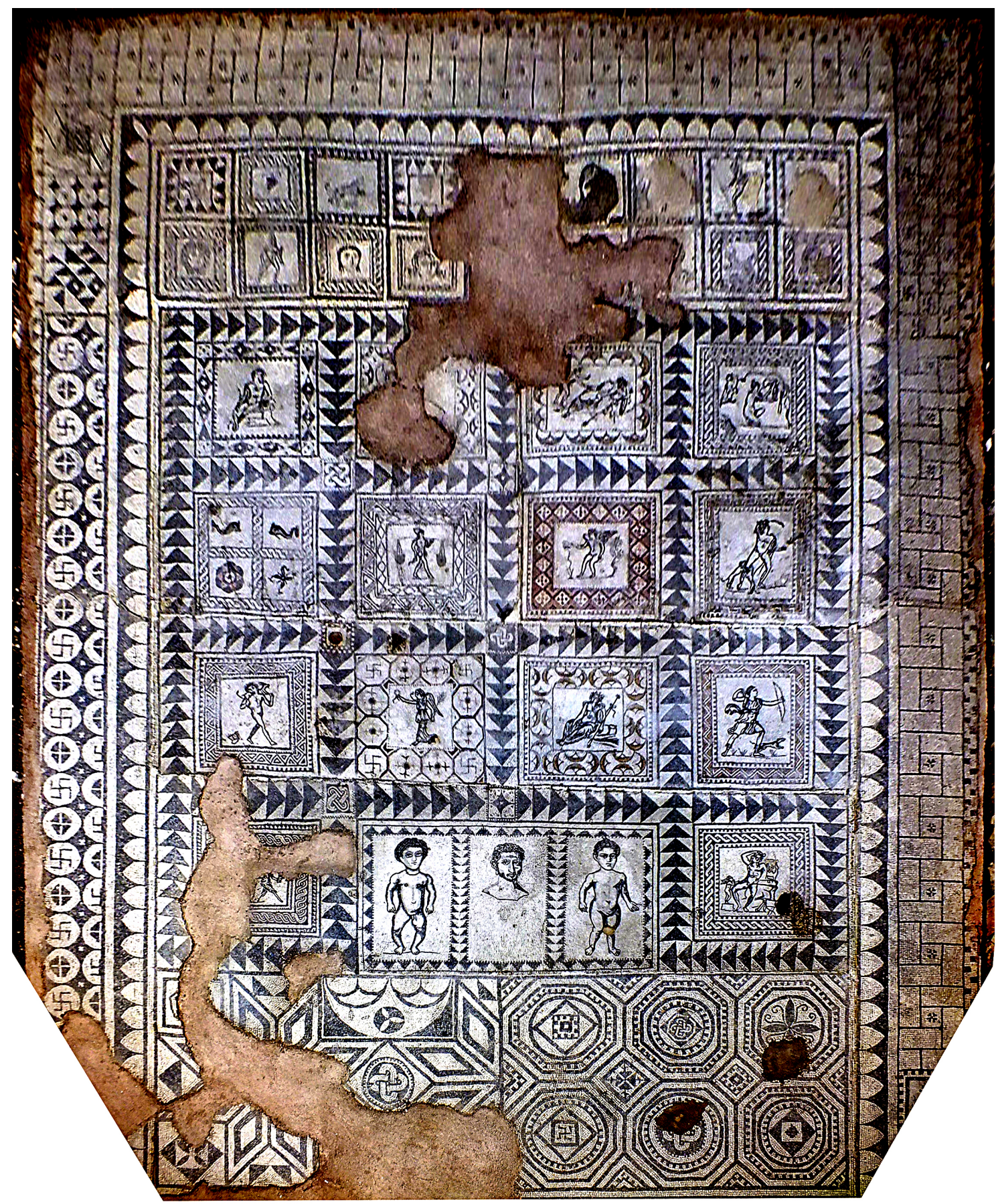

Figure 2

Overhead view of mosaic in Room 10. Photo courtesy of V. Popova.
The mosaic belongs to the second phase of the villa's construction, after the entrance to this space from the peristyle was closed and there were created new entrances, apparently from Room 9 to the E and possibly from Room 11 to the W. During this period, the building also was lavishly ornamented with marble wall revetment (including in Room 10), using stone from a local quarry. There were created mosaic pavements in other, adjacent spaces, such as Rooms 7, 8, 9, and 11, with pavements indicated by the letter $M$ in the plan. All of these mosaics have a variety of black and white geometric designs, with dark blue tesserae also used. The floor in Room 10 is made of predominantly dark blue, black, and white tesserae, highlighted by touches of red, green, yellow, and ochre. The entire villa was restored in the 1980s and is covered by a protective roof, allowing visitors to appreciate the building's overall volume and layout clearly. 


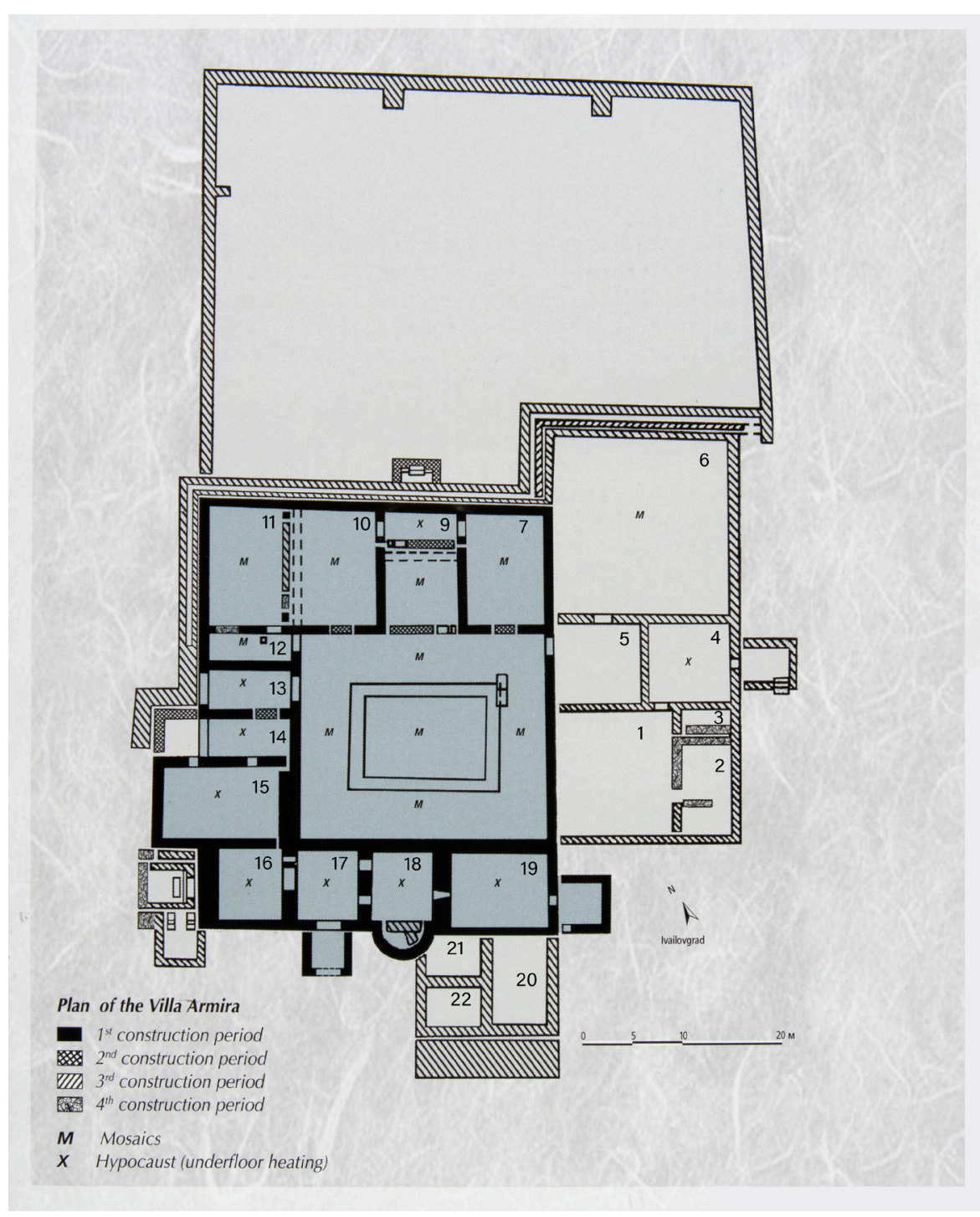

\section{Description}

The mosaic has a complex design (Figs. 2 - 4), focused on a large central checkerboard with seventeen compartments of figural content (Carpet 2), which are numbered for the reader's convenience. The carpet is surrounded by a continuous row of dark blue superposed isosceles triangles on a white ground ${ }^{2}$ that passes between the panels. At various points of intersection in the row of triangles occur single squares ornamented with a geometric motif such as a Solomon knot. S of this main zone is a mosaic section (Carpet 3 ) with two rows of smaller panels (eighteen in all), also containing figural elements. $\mathrm{N}$ of the main zone is a section of purely geometric design (Carpet 1), a supplementary panel perhaps serving as a surface for the placement of furniture. On the E side of this section appear one and a half large lozenge stars, linked by a poised square and flanked by a rectangle with a large pelta (a similar pelta presumably appeared below). By contrast, the $\mathrm{W}$ half of the same section contains two rows of tangent octagons embellished with diverse filler motifs.

Framing all three carpets of the field is a series of borders that (from the outermost border inward) consist of a simple meander, and on the $\mathrm{S}$ and $\mathrm{W}$ sides
Figure 3

Plan of Villa Armira, with $\mathrm{N}$ at the top. According to G. Kabakchieva, Splendour, 2012: fig. on 13. 
Figure 4

Schematic rendering of mosaic in Room 10 with numbers added. Based on J. Mladenova 1983: 157 fig. 8.

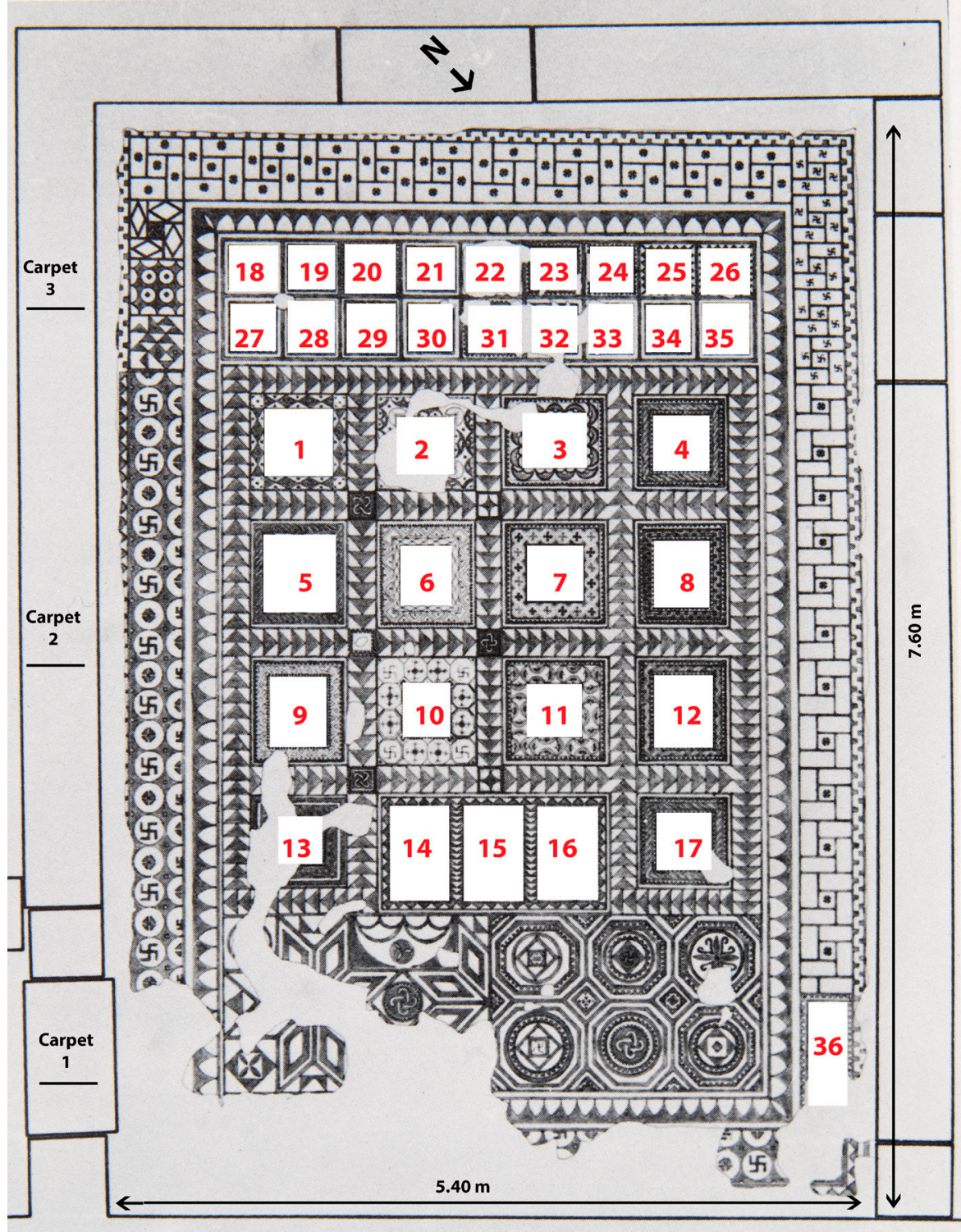

a row squares made of four rectangles enclosing a small square ornamented with a crosslet (Décor I: pl. 95a). On the $\mathrm{N}$ and E sides occurs a band of small circles and half-circles enclosing single swastikas and single crosslets, followed by a row of half-swastikas and half-crosslets. A small figural panel in the NW corner (Panel 36), which is damaged and contains a leaping deer, interrupts the band of squares made of four rectangles. Finally, we note a border of light-colored ogives and dark scales (Décor I: pl. 49a) that rings all three carpets.

The most prominent part of the mosaic in Room 10 is a group of three aligned compartments, Panels 14-16, centrally placed along the lower edge of Carpet 2 and interrupting the regular checkerboard; it represents a family group (Figs. 2 - 5). A narrow band of serrated sawtooth pattern surrounds all three panels, and two rows of small white superposed triangles pass between them. The father, in bust form, is flanked by his two nude infant children shown as standing figures a boy on the E side and a girl on the W. The portraits are strongly individualized. The father's head is placed in the upper part of the central compartment and turned slightly in three-quarter view to our right. He displays a full head of hair, a long nose, an earring hanging from his right ear, and a light beard and 
mustache. The figure is so naturalistic that he seems to have been drawn from life. Vania Popova (2015: 578) claimed that the father has Egyptian-looking features, comparable to some painted portraits of Hadrianic date from the Fayum region, and she suggested that the mosaic figure might be a self-portrait of the artist.
Figure 5

Mosaic Panels 14-16, family portraits.

According to G. Kabakchieva,

Splendour, 2012: fig. on 34.

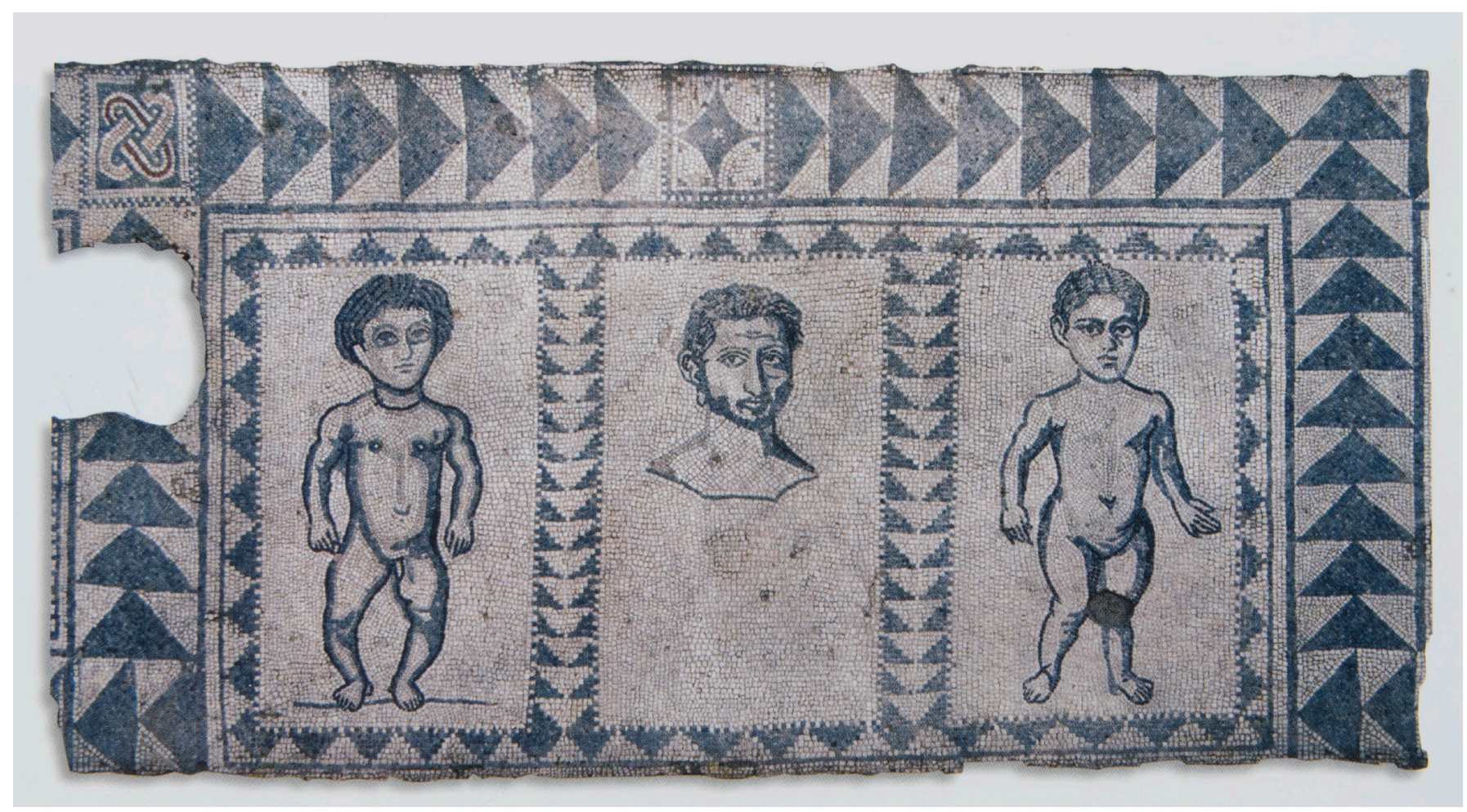

The two children, who look straight ahead, are characterized differently from each other, and show firm modeling of the contours. The boy, the younger of the two, exhibits full, wavy hair and a thin neck ornament, and he has a somewhat husky appearance, with both arms hanging down and his legs slightly bowed. By contrast, the girl has shorter hair, arranged in a sophisticated manner in parallel rows; she adopts a contrapposto stance and displays rounded hips. This child seems to gesture with her lowered left hand. Her expression is serious, and the eyes are finely rendered. There is no portrait of the children's mother, leading one to believe that she was deceased at the time the portraits were made (Popova 2015: 577). Conceivably, she was buried in the impressive tumulus found on the villa owner's estate at the site of Svirachi (Kabakchieva 2011: 226) ${ }^{3}$. Altogether, the trio of figures in the mosaic forms a rare instance of lifelike portraiture in the mosaic medium ${ }^{4}$.

To date, various scholars have considered the remaining figural imagery of the mosaic in Room 10, primarily mythological in content, to be unrelated to the

3 This scholar believes that the deceased individual was a Thracian princess, Kabakchieva 2012: 44.

4 A distant comparison is the family group depicted in a mosaic of the 4th-century villa at Piazza Armerina, which shows children of older age with their mother, all finely draped, but those figures are not as closely observed nor as sharply characterized as the ones seen in the Villa Armira mosaic; for the Sicilian example, Carandini et al. 1982: 331-332, 334 fig. 200 pl. LV; Dunbabin 1999134 fig. 132. Another fine mosaic portrait of an adult is the image of the poet Virgil in a 3rd-century pavement from Sousse-Hadrumetum, but the latter individual is of a generic type and not as strongly characterized as the father in the Bulgarian pavement; cf. Yacoub 1995: 143-144 fig. 65; Pappalardo -Ciardiello 2010 242-246 figs. on same pages. 
family portraits 5 . I disagree, and I think the other panels are directly connected to the portraits by the notion of paideia or education, affirming traditional social values and transmitting these to the next generation. These episodes symbolize the classical culture which the infants and their father inherited. Particular themes are emphasized, among them the world of the god Dionysos, which is alluded to in various ways. These include an image of the god himself, depictions of members of his entourage, references to theatrical performances, and a mythical scene about Ariadne. It seems that other images are gender-related. Some are intended to instruct the boy about the manly virtues of warfare and distinction in battle, whereas other mythological episodes focus primarily upon a female model, the goddess Artemis. There also are references to music-making (perhaps reflecting small recitals that actually took place in Room 10), and to Eros (a young figure appealing to both mortal infants represented in the mosaic). One also sees allusions to the marine environment and the everyday activity of fishing. It is a varied iconographic repertory.

\section{Carpet 2}

I shall now describe and illustrate the figural panels in Carpets 2 and 3. Carpet 2 contains 14 square panels outside the family group at its lowest level (the latter three panels are of rectangular shape), and the former occur in four horizontal rows, counting downward from the uppermost to the lowest level. We shall proceed from left to right in each row, with the panels numbered consecutively (see Fig. 4).

- Panel 1: a seated satyr who holds a pedum or hunting stick looks off to his left; a border of lozenges and a row of dentils frame the satyr (Fig. 6).

Figure 6

Mosaic Panel 1, seated satyr. Photo courtesy of V. Popova.

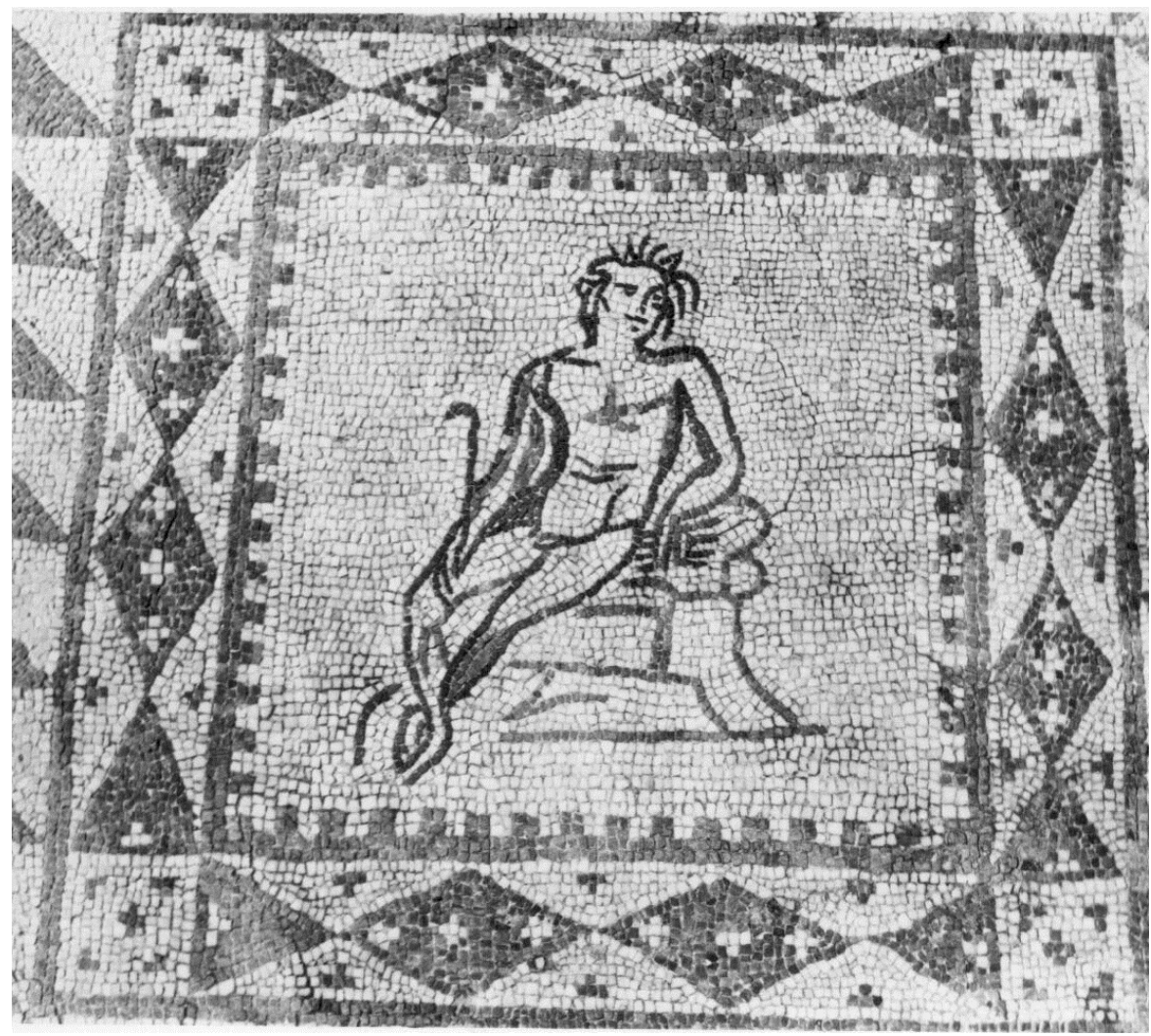

5 For example, Mladenova 1983: 155, who considered the mythological subjects represented to be standard in the mosaic repertory and without any further significance; Dunbabin 1999: 321, who expressed a similar point of view; and Valeva 2015: 447, who did not mention any link between the portraits and the mythological images. 
- Panel 2: the emblema is missing; the panel's border consists of paired peltae.

- Panel 3: a young satyr bends over the sleeping Ariadne, seen from the back and next to whom lies a thyrsos; a row of single peltae and an external row of dentils form the border (Fig. 7).

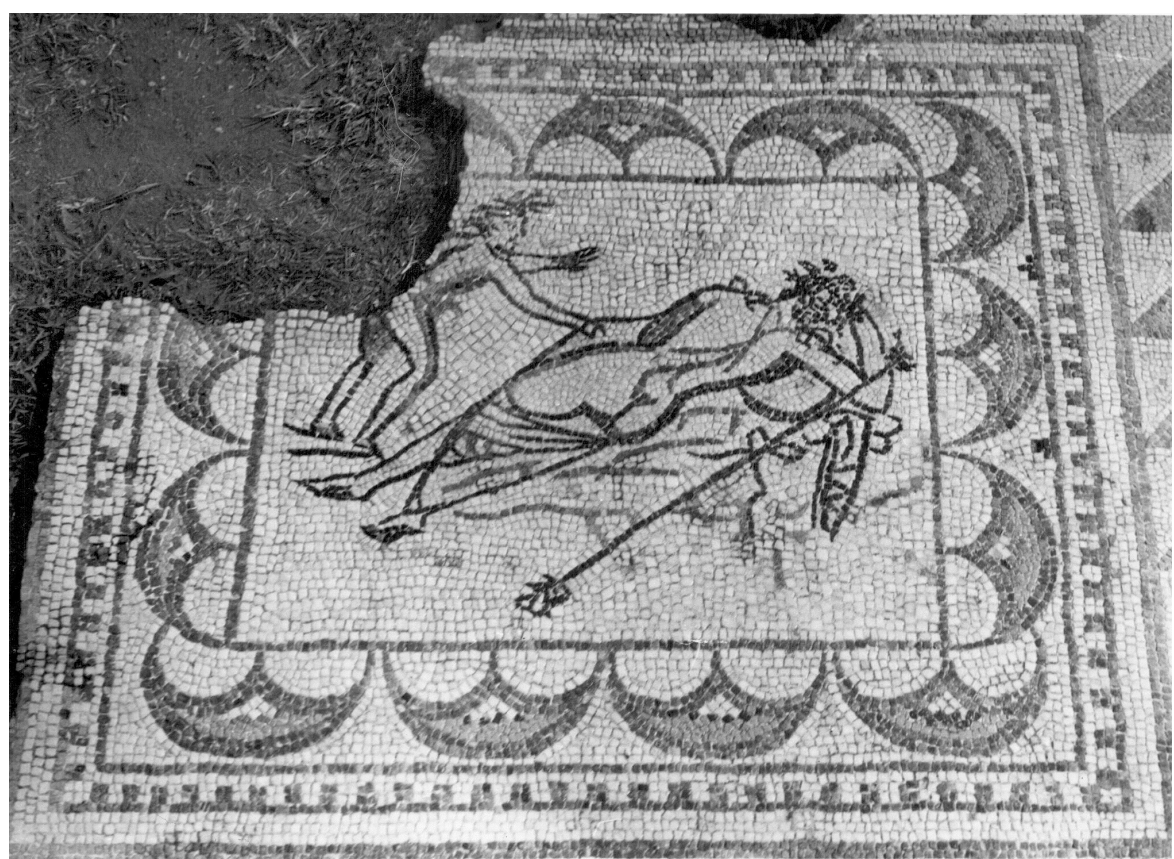

- Panel 4: nude, crouching Artemis, viewed in profile and with her bow, quiver, and drapery placed nearby, is observed by Actaeon while at her bath; the border is a guilloche band framed by rows of dentils (Fig. 8).
Figure 7

Mosaic Panel 3, sleeping Ariadne.

Photo courtesy of V. Popova.
Figure 8

Mosaic Panel 4, Artemis bathing.

Photo courtesy of V. Popova.

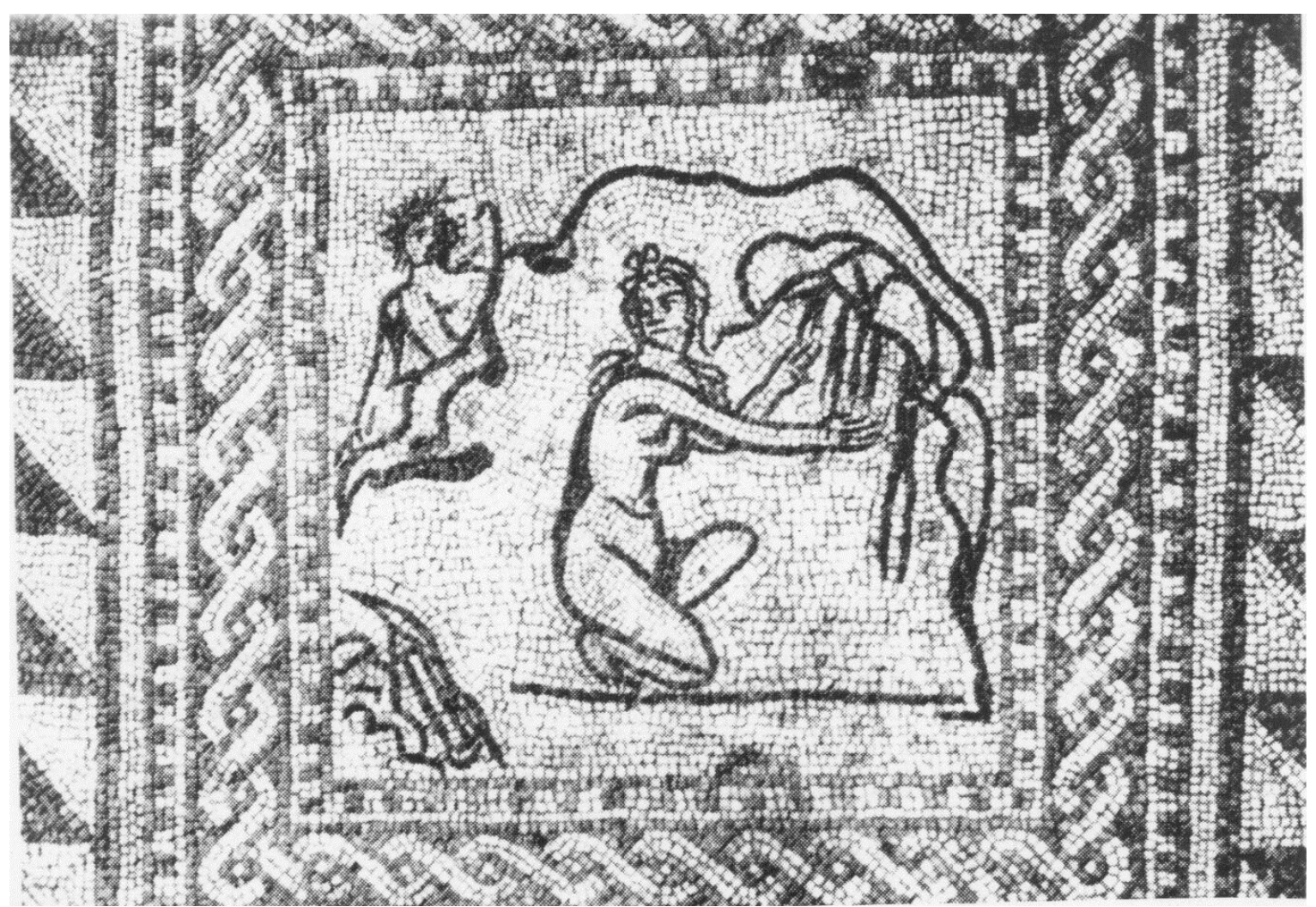


Figure 9

Mosaic Panel 5, dolphins and rosettes. Photo courtesy of V. Popova.

Figure 10

Mosaic Panel 6, fisherman. According to Kabakchieva 2012: fig. on 35.

- Panel 5: it is divided by a simple guilloche into four quadrants. displaying a pair of inward-turned dolphins above and a pair of rosettes, one very full and the other with thin, curved leaves, below (Fig. 9).

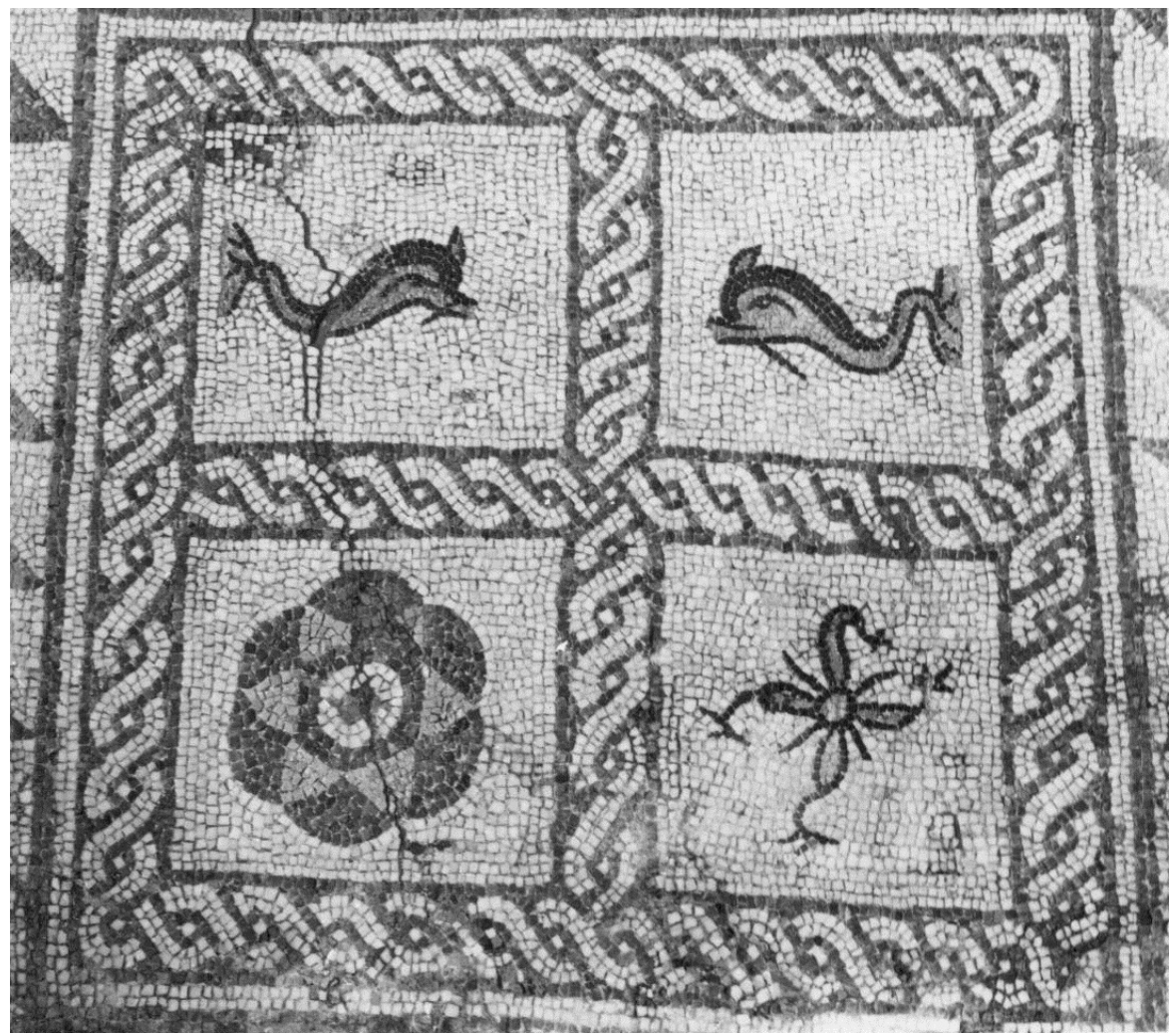

- Panel 6: a lightly-clad fisherman wearing a cap walks rightward carrying two baskets of fish hanging from a shoulder pole and a single fish in his lowered hand; a border of zigzag pattern and a row of lozenges frame the panel (Fig. 10).

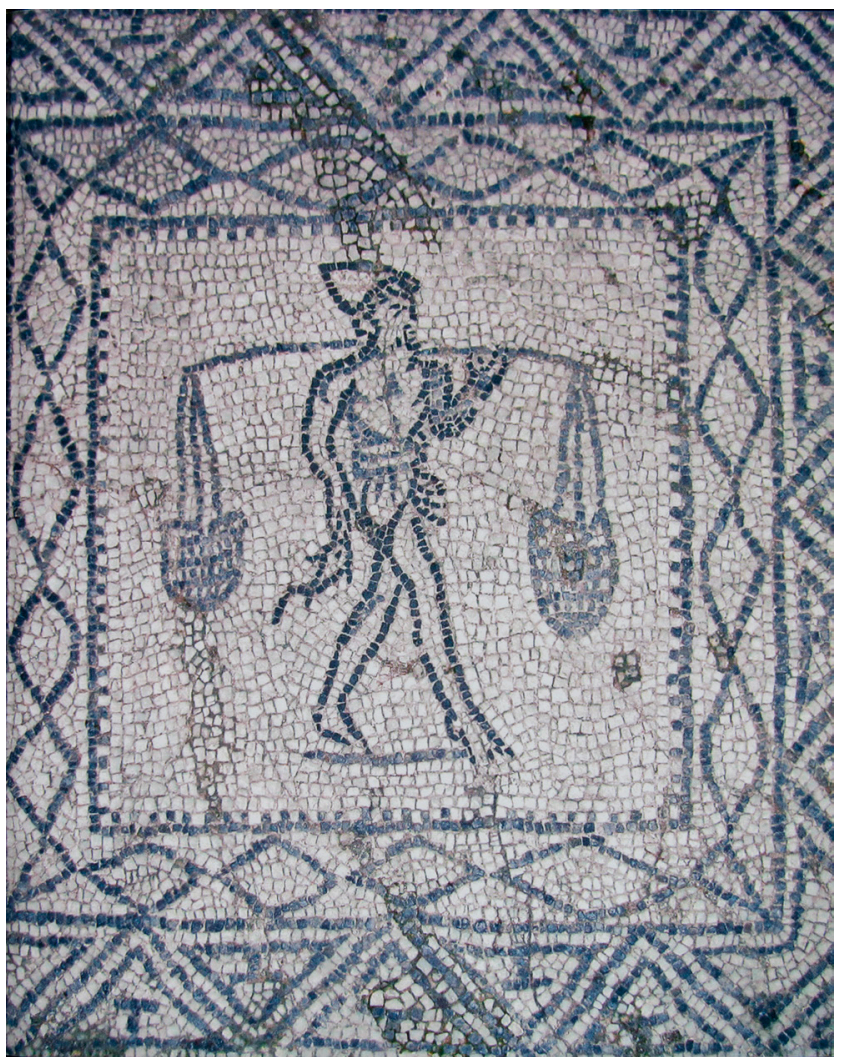


- Panel 7: Eros holding a wreath stands between two plants; a row of poised squares highlighted in red and an external row of dentils frame the panel (Fig. $11)$.

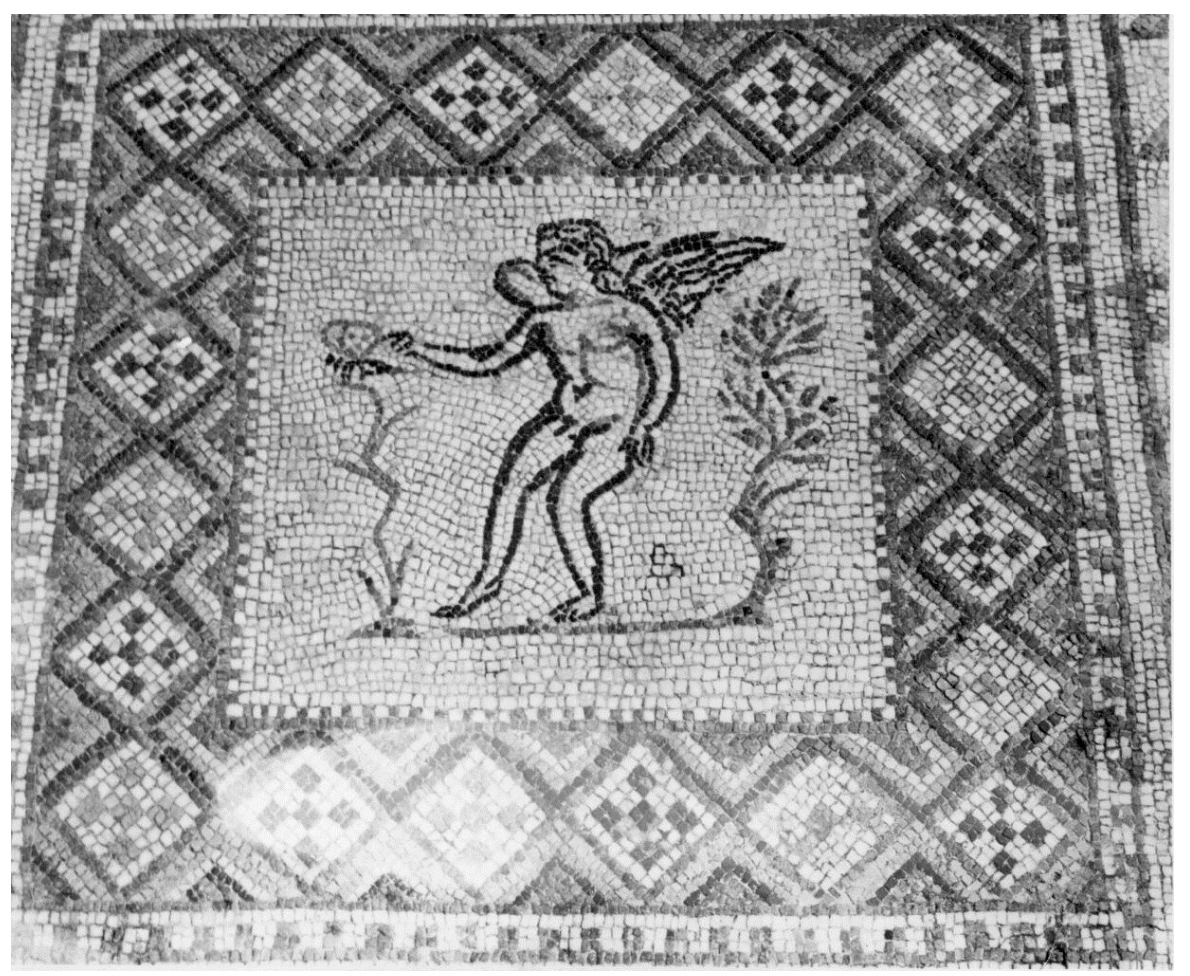

- Panel 8: nude Actaeon, wearing a light cloak over one shoulder, tries to defend himself with a hunting stick from two attacking hounds, incited by Artemis; there is a border of two rows of dentils framing a broken meander (Fig. 12).

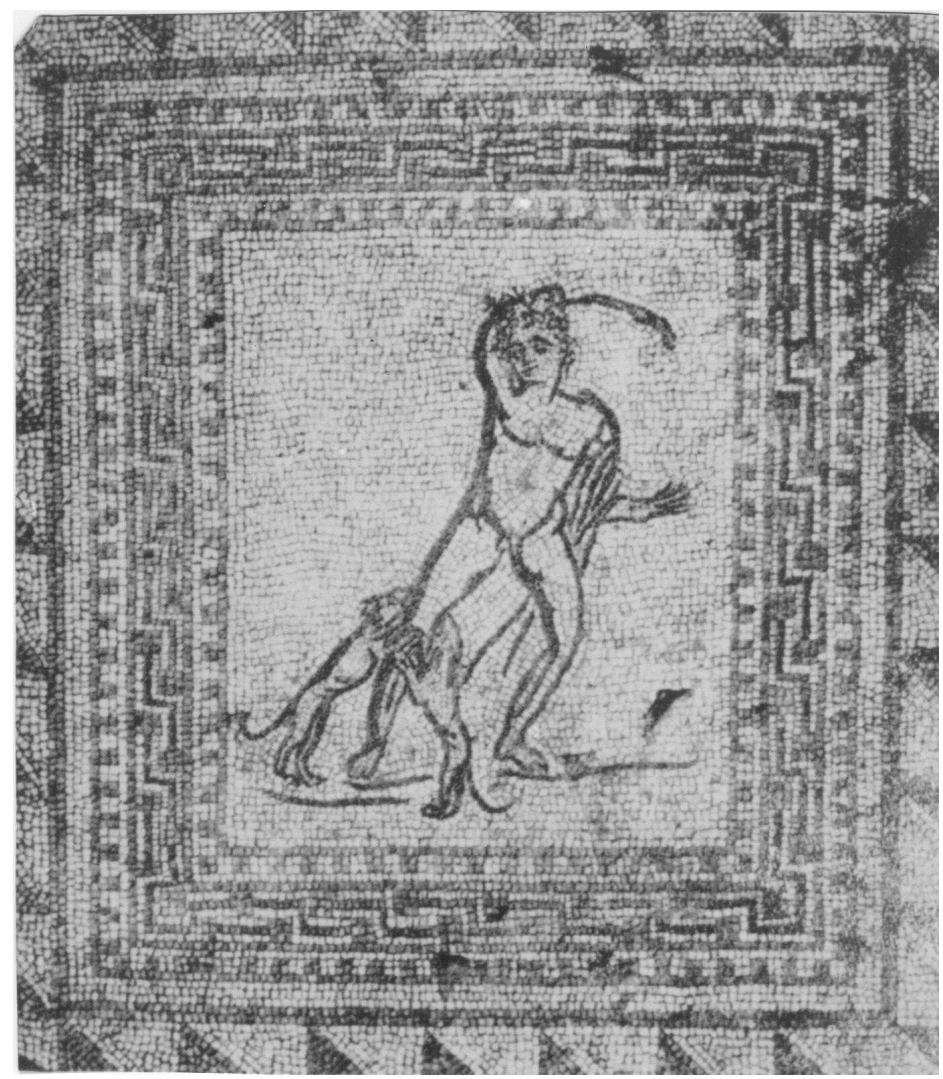

Figure 11

Mosaic Panel 7, Eros.

Photo courtesy of V. Popova.
Figure 12

Mosaic Panel 8, Actaeon attacked by hounds. Photo courtesy of V. Popova. 
Figure 13

Mosaic Panels 9 and 10, satyr and Nike. According to Kabakchieva 2012: fig. on 32.

- Panel 9: a satyr wearing a wreath walks forward carrying a goat on his shoulders and holding a pedum, as a syrinx lies at his feet; rows of dentils enclose a zigzag pattern in the border (Fig. 13, left).

- Panel 10: Nike wearing a peplos holds a fillet crown tied with ribbons and a palm branch, as she strides to the left; a border of elongated octagons enclosing single swastikas and circles framed by paired lilies (Décor I: var. of pl. 25d) forms the border (Fig. 13, right).

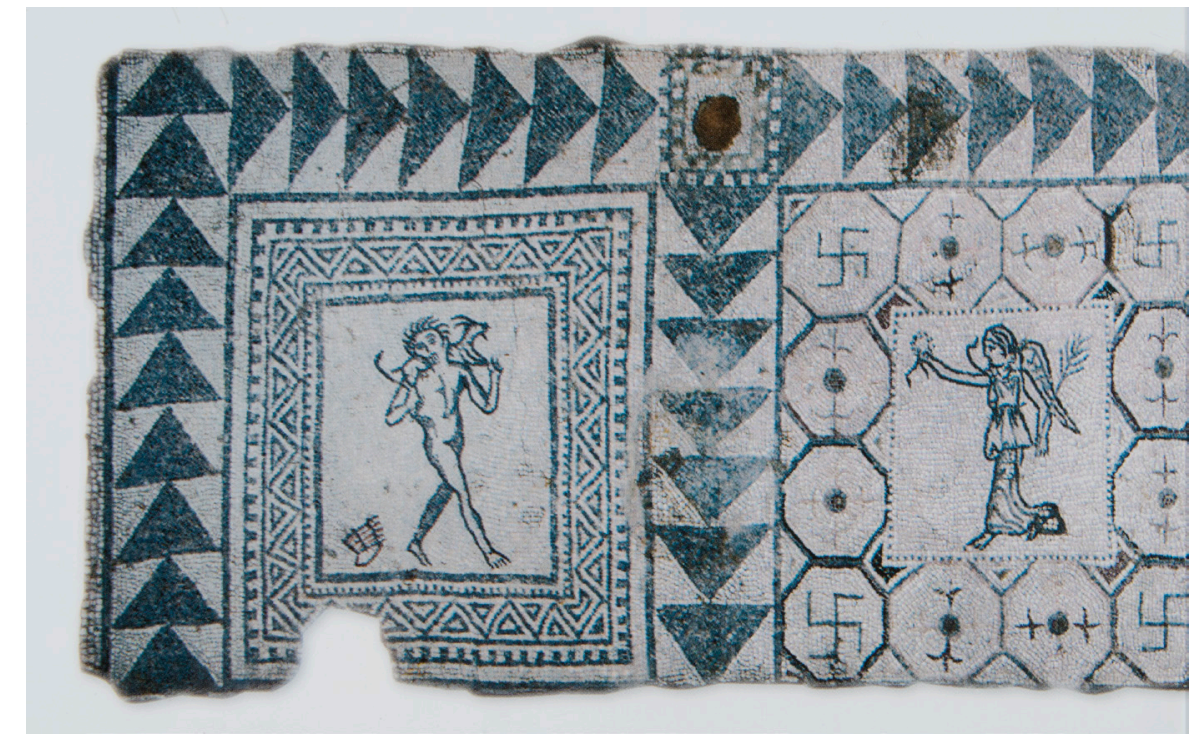

- Panel 11: Dionysos, half-nude and with a cloak on his shoulders sits on a rock gazing outward while holding his thyrsos; a border of pairs of yellow backed peltae emphasizes the figure visually (Fig. 14, left).

- Panel 12: Artemis, who wears a short tunic, a sash around her waist, and boots, gracefully draws an arrow to shoot with her bow, as a running hound is seen alongside; a border of shaded zigzag pattern (Décor I: pl. 9a), colored red and set between rows of dentils, accents her visually (Fig. 14, right).

Figure 14

Mosaic Panels 11 and 12, Dionysos and Artemis. According to Kabakchieva 2012:

fig. on 33 .

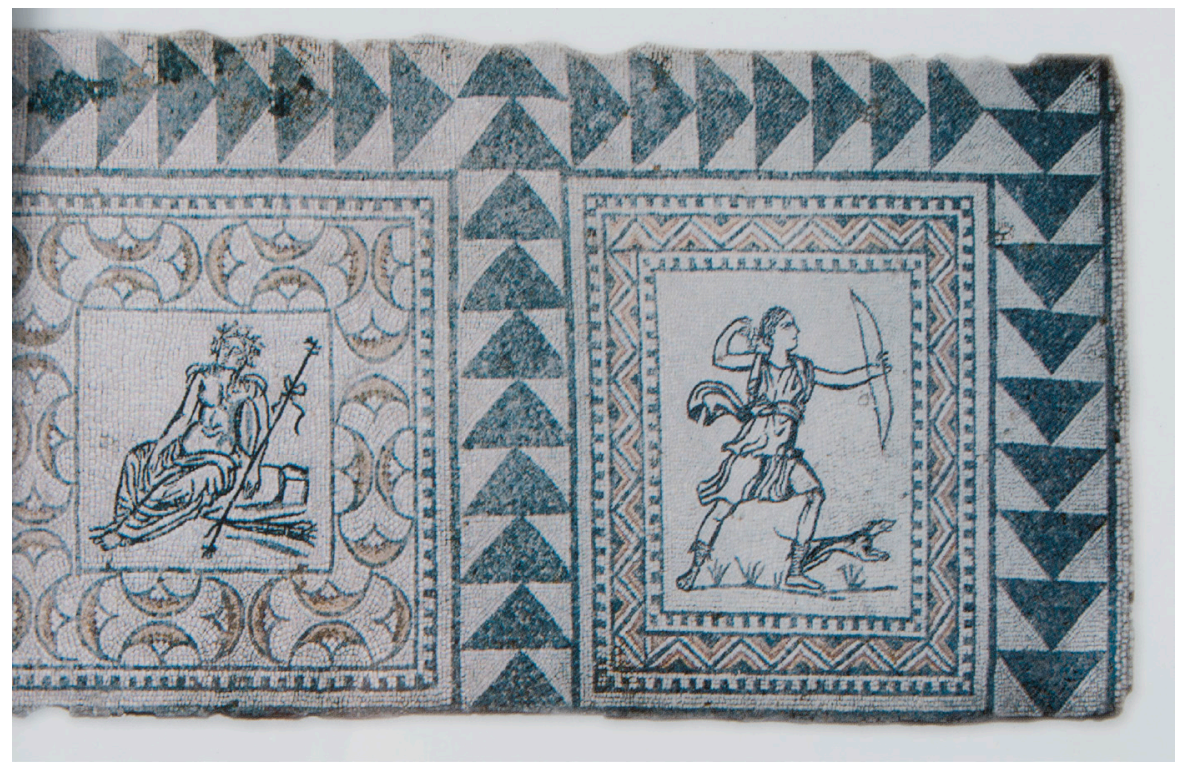


- Panel 13: one sees only the lower part of the damaged Pan with his goat legs stepping forward and holding what may be a syrinx; a guilloche band framed by rows of dentils composes the border (Fig. 15).

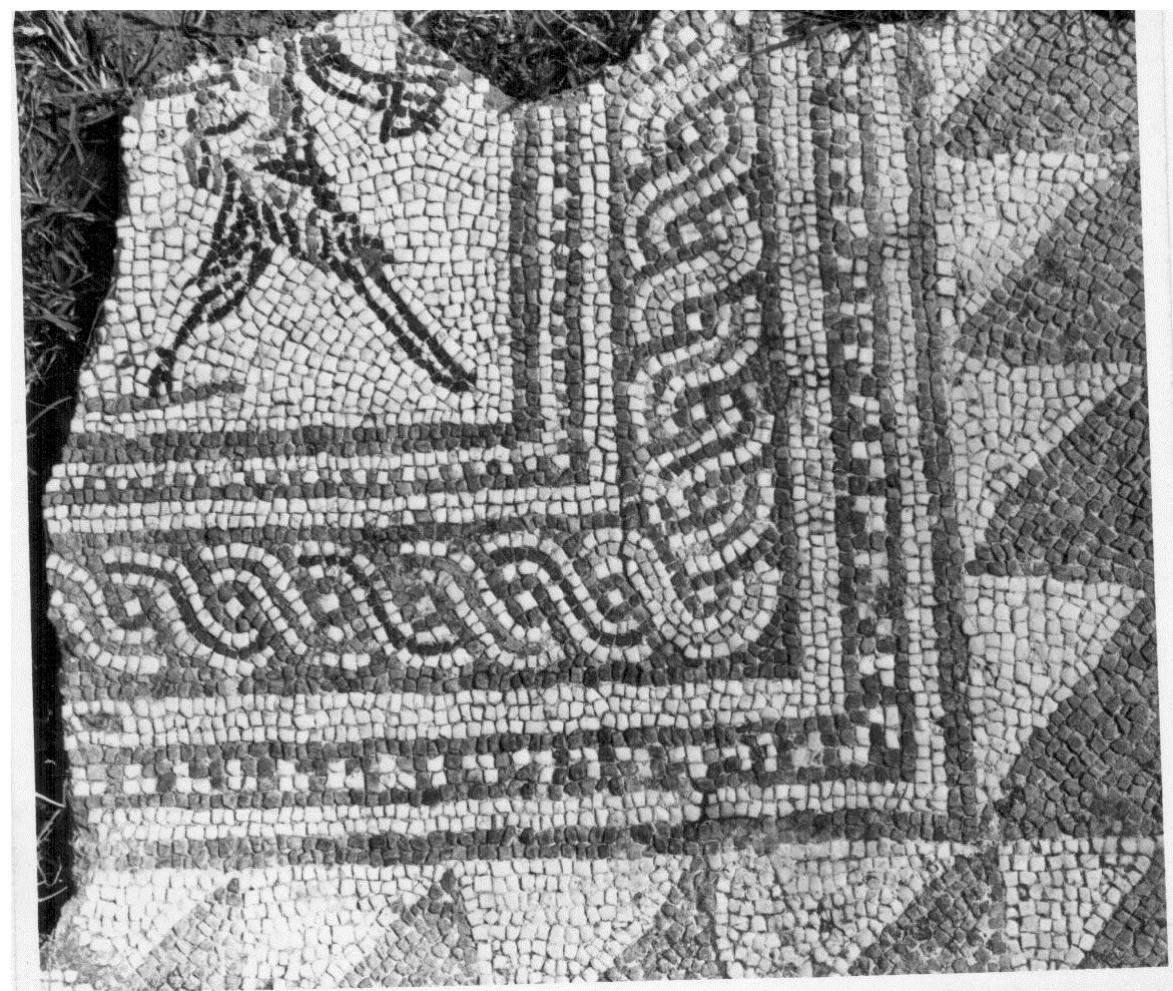

- Panel 14: a boy, whose father may have been the villa owner, is shown; a sawtooth pattern (Décor I: var. of pl. 10k) and a row of superposed isosceles triangles frame the panel (Fig. 5, left).

- Panel 15: a man, who presumably was the villa owner, appears in bust form; a sawtooth pattern and rows of superposed isosceles triangles frame the panel (Fig. 5, center).

- Panel 16: one sees the daughter of the man in the adjacent panel; a sawtooth pattern and rows of superposed isosceles triangles form the panel's border (Fig. 5 , right).

- Panel 17: the nude Apollo sits casually on a rock, bending one arm over his head and supporting his partly gold cithara with his other arm, as a small Eros (his bow and quiver cast aside) leans on Apollo's knee; a guilloche band enclosed by rows of dentils forms the border (Fig. 16).

\section{Carpet 3}

The two rows of smaller figural panels at the top of the mosaic field continue the numbering begun in Carpet 2, going from left to right and starting with the upper row:

- Panel 18: there appears a bird framed by a black and white dog's tooth pattern (Décor I: pl. 10c) (Fig. 17, top row, left end).

- Panel 19: one sees a single hedera framed by a guilloche band (Fig. 17, top row, center).

- Panel 20: there appears a leaping panther turned rightward and framed by dentils (Fig. 17, top row, right).
Figure 15

Mosaic Panel 13, Pan.

Photo courtesy of V. Popova. 
Figure 16

Mosaic Panel 17, Apollo with Eros. Photo courtesy of V. Popova.

Figure 17

Mosaic Panels 18-20, bird, hedera, panther (upper row); and Panels 27-29, Gorgoneion, Ares (?), head or mask (lower row).

Photo courtesy of V. Popova.
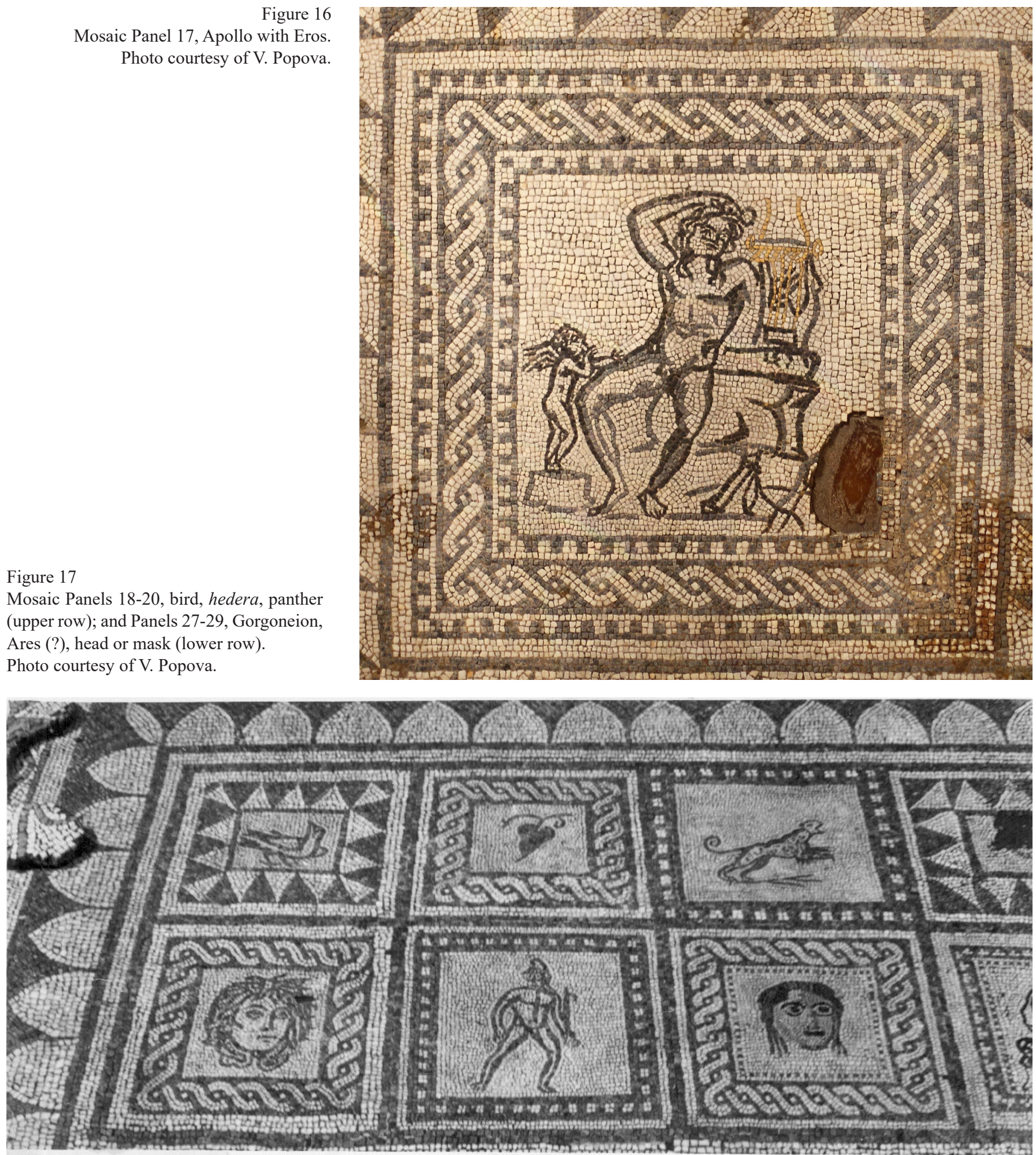

- Panel 21: the motif inside a frame of dog's tooth pattern is a bull's head.

- Panel 22: completely obliterated.

- Panel 23: one sees a fragmentary theater mask framed by a row of dentils (Fig. 18).

- Panel 24: the image is almost completely destroyed. 


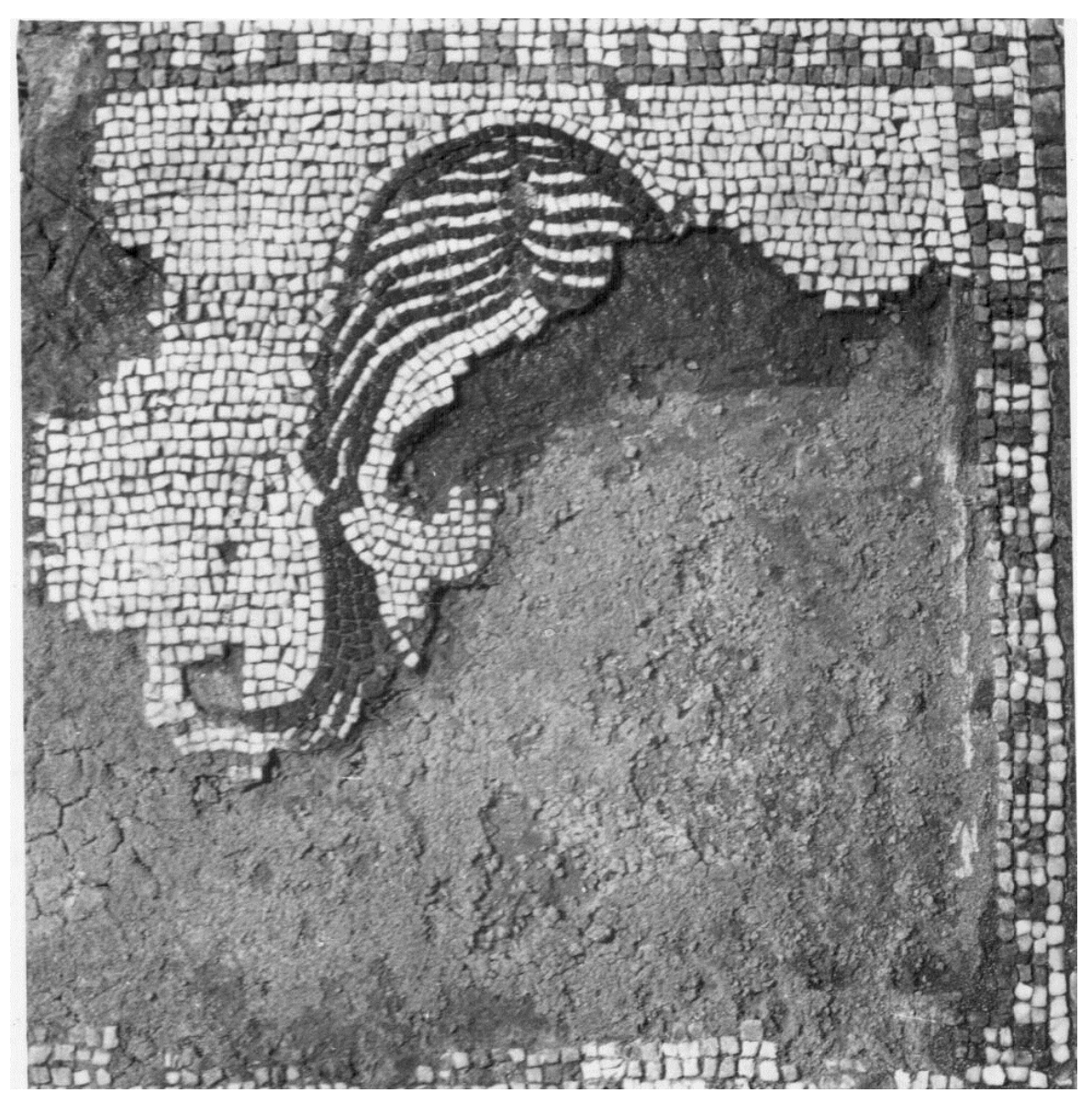

- Panel 25: there appears a partly damaged, nude soldier with a helmet, sword, and shield who looks rightward; the border displays a sawtooth pattern (Fig. 19, top row, left).

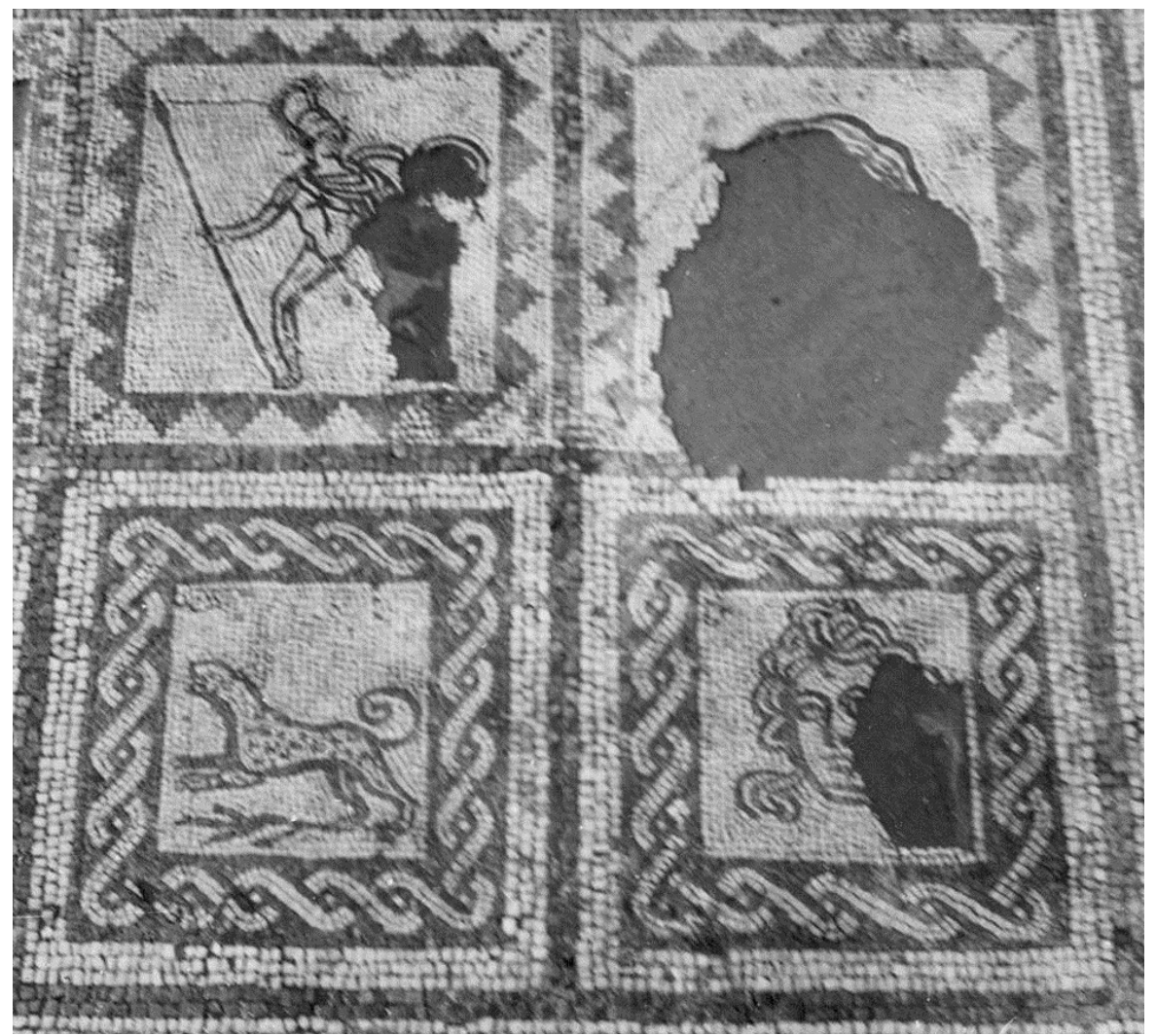

Figure 18

Mosaic Panel 23, mask.

Photo courtesy of V. Popova.

\section{Figure 19}

Mosaic Panels, 25 and 26, soldier and mask (upper row); Panels 34 and 35, panther and mask (lower row). Photo courtesy of V. Popova. 
- Panel 26: damaged beyond recognition, but perhaps originally taking the form of a mask.

- Panel 27: a well-preserved Gorgoneion ${ }^{6}$ is seen; the surrounding frame is a simple guilloche (Fig. 17, bottom row, left; also Fig. 20).

Figure 20

Mosaic Panel 27, Gorgoneion. Photo courtesy of V. Popova.

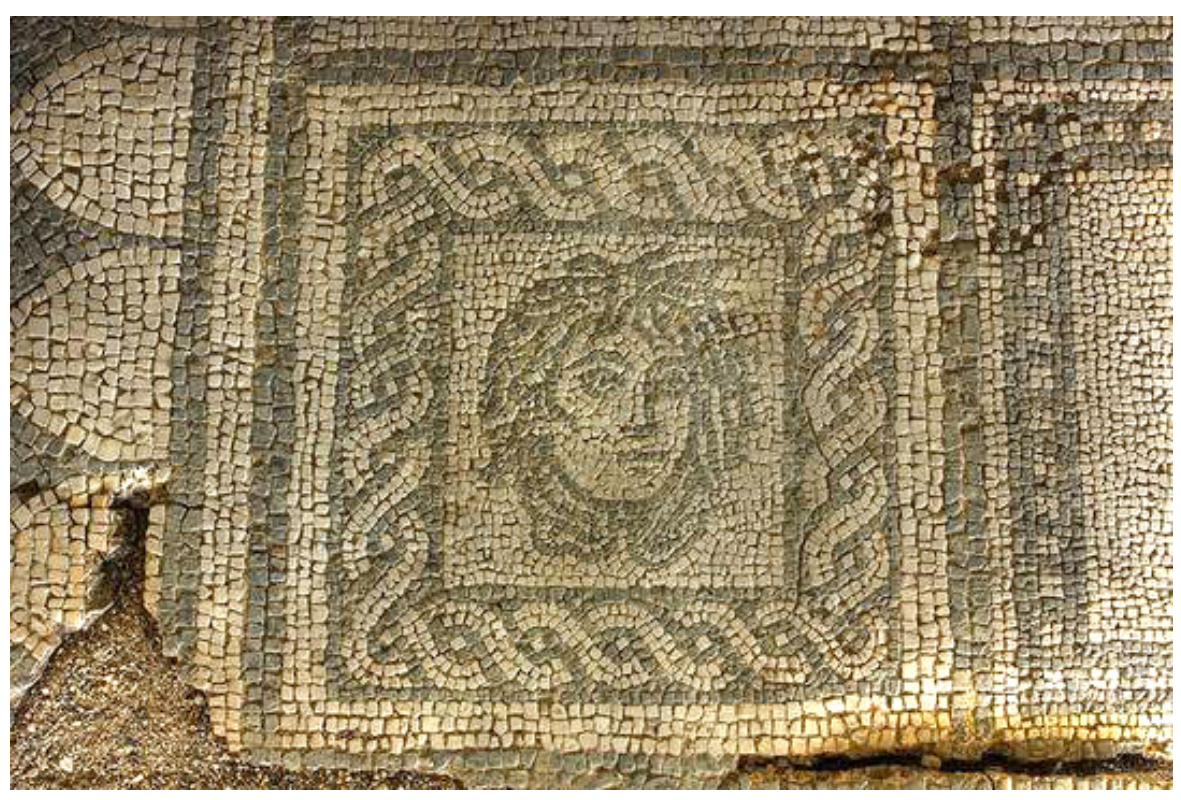

- Panel 28: a nude standing warrior with a sword and helmet, perhaps to be identified as the god Ares, faces leftward; a row of dentils forms the border (Fig. 17 , bottom row, center).

- Panel 29: a head or theater mask of seemingly tragic expression occupies the panel; the border consists of a simple guilloche (Fig. 17, bottom row, right).

- Panel 30: there appears a female head or mask with full hair spreading to the sides, seemingly of comic type; a broad band and dentils frame the panel.

- Panel 31: destroyed.

- Panel 32: mostly destroyed.

- Panel 33: there remains only a fragment of what may have been a mask.

- Panel 34: one sees a leaping panther similar to the one in Panel 20, but oriented in the opposite direction; the border is a simple guilloche (Fig. 19, bottom row, left).

- Panel 35: one sees a female head or theater mask with long hair, similar to the one in Panel 30 and perhaps of comic type; a simple guilloche forms the border (Fig. 19, bottom row, right).

- Panel 36: this damaged panel, which interrupts the mosaic border in the NW corner, encloses a leaping deer, perhaps linked to the goddess of the hunt in Panel 12; the border has a row of dentils and a dark band (Fig. 21).

6 Cf. a different Gorgoneion found in a later, $3^{\text {rd }}$ century pavement in Room 6 of the Villa Armira, Kabakchieva 2011: 227 fig. 7; Kabakchieva 2012: 40 and fig. on same page. 


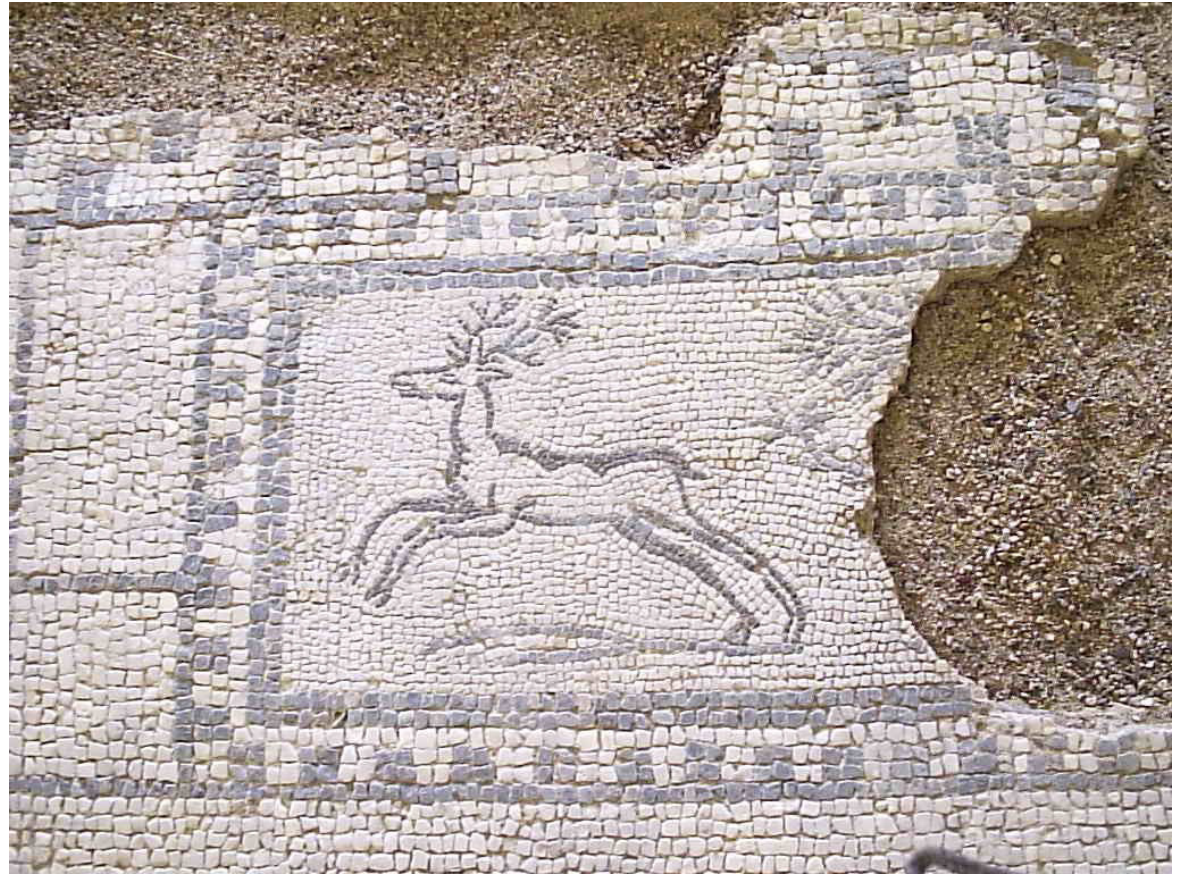

\section{Interpretation}

The contents of this mosaic are very diverse, displaying convincing portraits and mythological subjects, and including a few references of an everyday sort. In the author's view, the imagery seems intended to instruct the two real-life children in the mosaic about classical culture and some of the moral and social precepts it teaches. As noted above, several of the examples represented seem to allude to both male and female role models, in addition to reflecting actual activities that may have occurred in Room 10 in Antiquity. The artistic arrangement is eclectic yet meaningful.

\section{1) Dionysos}

The most prevalent theme is the Dionysiac milieu, stressing the god's universal importance by various means. Dionysos brings worldly prosperity (perhaps symbolized by the hedera, which also can be seen as a decorative motif), masters large felines (panthers), patronizes the theater (signified by the masks represented), and is an exemplar of married life (in his relation to Ariadne). This deity (seen in Panel 11) appears immediately above the mortal children in the mosaic. Members of Dionysos's retinue, moreover, can be found in panels depicting two satyrs and Pan, aligned vertically on the pavement's E side (Panels $1,9,13$ ), and in the episode of the sleeping Ariadne discovered by a satyr, located just right of center on the mosaic's main axis (Panel 3). The theater masks in Carpet 3 can be compared to those represented in mosaics in homes in other Roman provinces ${ }^{7}$, where such objects often imply a literary interest on the part of the mosaic patrons. That also may have been true of the proprietor of the Villa Armira. One can imagine his sponsoring dramatic recitations and performances
Figure 21

Mosaic Panel 36, leaping deer, facing S. Photo courtesy of V. Popova.

7 An example is the assortment of masks in the triclinium pavement of the House of the Masks at Sousse, Foucher 1965: 51-57, 61-72, drawing on 25. Another mosaic from that home shows a poet and an actor with masks, Foucher 1965: 15-16 fig. 20; Dunbabin 2016: 83 fig. 3.23. Cf. mosaics with masks from other Roman provinces, the House of Menander at Mytilene, Charitonidis et al. 1970: 36-37 pl. 18,1; 53 pl. 22,1; pavements with masks from Aix-en-Provence and Vienne in Gaul, Balmelle - Darmon 2017: 148-149 figs. 180-184; from Butrint in Albania, Raynaud - Islami 2018: 71-80 figs. 75, 79-81, 86-87; and more examples from other regions, ibid. 219-223. 
of scenes of plays of limited size in Room 10, related to theatrical episodes depicted in Roman houses elsewhere ${ }^{8}$. There also occur numerous allusions to real life music-making in domestic settings outside Thrace9.

\section{2) Artemis, Apollo and Ariadne}

We now turn to panels in the Villa Armira mosaic that seemingly were intended to instruct the villa owner's daughter and son in other ways. In the right half of Carpet 2, we observe a few figural episodes that refer to Artemis as a model of feminine prowess in the hunt (Panel 12), and as the goddess who severely punishes Actaeon (Panel 8) for violating her privacy while she is bathing (Panel 4). Artemis's cynegetic activity is seemingly underscored by the presence of a leaping deer in the nearby mosaic border (Panel 36), for this type of animal is a favorite quarry of the deity's. Immediately below Artemis in Carpet 2 is her twin brother Apollo (Panel 17), who is depicted as a musician, perhaps because he inspired actual musical performances in Room 10. Other musical references occur both in the illustration of a satyr with a syrinx (Panel 9), and of Pan holding what also looks like a syrinx (Panel 13).

The other virtuous mythological female in the mosaic is Ariadne. As the future spouse of Dionysos, she symbolizes happy conjugal life, which perhaps is the intended destiny of the true-to-life girl in the pavement. The figure Eros (Panel 7), accentuated by the bright red frame around him, is understood as the agent of pure, honorable love.

\section{Other Masculine Models}

In the pavement's right and left halves, there occur references to the manly pursuit of warfare and its rewards. There are two armed figures in Carpet 3, one a soldier of unspecified type (Panel 25) and the other a nude warrior who may be the god Ares (Panel 28). The notion of heroic achievement in battle is underscored by the presence of Nike, holding a beribboned crown and the palm branch of a victor (Panel 10). The Gorgoneion (Panel 27), an apotropaic emblem, helps bring good fortune to those undertaking heroic exploits, and the bull's head in Panel 21 could allude to animal sacrifices following a successful military campaign.

Finally, the references to fishing and the sea (Panels 5 and 6) stress nature's bounty and mankind's benefit from it. Rather than making a local topographical reference, this aquatic imagery seems to have a more generalized meaning, which, like emblems of air and land, namely, the bird and hedera and rosettes (Panels 18 and 19), evokes the prosperity of the villa owner' estate. The hedera also may have an ornamental function.

8 On performances in the home, Dunbabin 2016: 81, 83-84. Cf. the mosaic representation of a theatrical troupe from the House of the Tragic Poet at Pompeii, Pappalardo - Ciardiello 2010: 186, 188-189 figs. on 188-189, 191-193. Wall paintings in private houses also feature theatrical imagery that reflects the proprietor's cultural awareness and perhaps too the occurrence of domestic entertainments, Parrish 1995; 154-158 fig.13; Zimmermann - Ladstätter 2011: 115, 117 figs. 204-205.

9 See, for example, the celebrated Mosaic of Female Musicians that decorated the triclinium of a private house in Mariamin, dated to ca. 400 AD, Balty 1977: 94-99 figs. on same pages. 


\section{Conclusion}

The mosaic in Room 10 of the Villa Armira has special interest, because it combines very lifelike family portraits with mythological episodes and downto-earth images for the education or paideia of the proprietor's children. The latter individuals learned about adult behavior and social values through the legendary examples set before them in a private area of the home. It is a form of moral and cultural training by artistic means. The Bulgarian pavement differs from several other Roman mosaic depictions of children, such as those seen in one part of the villa at Piazza Armerina (Carandini et al. 1982: 272-287 figs. 163-176 pls. XL-XLII), which show real-life children imitating adult activities (hunting small game, gathering flowers, enacting circus races with pairs of birds, and performing as musicians and actors). Also different is the extensive series of narrative episodes about the boy Kimbros depicted in a late antique mosaic from Syria (Marinescu et al. 2005; Cox et al. 2015), which are biographical in nature rather than having a didactic purpose.

Overall, the mosaic in Room 10 of the Villa Armira incorporates picturesque and engaging figures and scenes in a manner that is stylistically elegant and well executed, technically. It is a pacesetter for ancient Thrace, showing how one family in that province fully assimilated Greco-Roman culture during the High Empire, and created a lasting personal record for posterity. It matches the richly developed décor found in other parts of the same villa ${ }^{10}$.

10 Aside from black and white mosaics found in several other spaces besides Room 10 in the villa, the building's peristyle features a large swimming pool in its center, framed by white marble columns and a marble balustrade punctuated by herms. The walls of the surrounding porticoes are covered with marble revetment punctuated by elegant pilasters. On these various types of decoration, see Mladenova 1983: 150-153, 157-165 figs. 3-7, 11-15; Mladenova 1991: 191-193; Kabakchieva 2011: 223-228; Kabakchieva 2012, front cover, 14, 16 figs. on 9, 17-31. 


\section{Bibliography - Kaynaklar}

Balmelle - Darmon 2017

Balty 1977

Carandini et al. 1982

Charitonidis et al. 1970

Cox et al. 2015

Darmon 2018

Décor I

\section{Dunbabin 1999}

Dunbabin 2016

Foucher 1965

Kabakchieva 2002

Kabakchieva 2010

Kabakchieva 2011

Kabakchieva 2012

Marinescu et al. 2005

Mladenova 1983

Mladenova 1991

Pappalardo - Ciardiello 2010

Parrish 1995

Popova 2015

Raynaud - Islami 2018

Valeva 2015

Yacoub 1995
C. Balmelle - J.-P. Darmon, La mosaïque dans les Gaules romaines, Paris.

J. Balty, Mosaïques antiques de Syrie, Brussels.

A. Carandini, A. Ricci, M. deVos, Filosofiana, La Villa di Piazza Armerina: Immagine di un aristocratico romano al tempo di Costantino, Palermo.

S. Charitonidis. L. Kahil, R. Ginouvès, Les mosaïques de la Maison du Ménandre á Mytilène, Bern.

S. Cox, C. Marinescu, R. Wachter, "Bringing Up Baby: Five Unpublished Panels in the Kimbros Mosaic Series”, CMGR XII, Verona, 105-111.

J.-P. Darmon, Mythes et images en mosaïque antique: Scripta (musi)varia; Recueil de textes (1963-2013), Paris.

C. Balmelle - M. Blanchard Lemée - J. Christophe - J.-P. Darmon - A.-M. Guimier Sorbets - H. Lavagne - R. Prudhomme - H. Stern, Le Décor Géométrique de la Mosaïque Romaine I, Paris, 1985.

K. Dunbabin, Mosaics of the Greek and Roman World, Cambridge.

Theater and Spectacle in the Art of the Roman Empire, Ithaca and London.

L. Foucher, La Maison des Masques à Sousse: Fouilles 1962-1963, Tunis.

G. Kabakchieva, "The Rescue Archaeological Excavations of the Big Tumulus/Mound Burial at the Village of Svirachi, Ivailovgrad Region", Archaeaological Discoveries and Excavations in 2001, XLI National Archaeological Conference, Sofia, 106-107.

G. Kabakchieva, "The Big Mound of the Family Necropolis of the Ancient Villa Armira”, D. Triantaphillos - D. Terzopoulou (eds.), Horses and Wagons in the Ancient World, 279-296.

G. Kabakchieva, "Die antike Villa Armira - eine neue Touristattraktion in Bulgarien”, G. von Bülow - H. Zabehlicky (eds.), Bruckneudorf und Gamzigad: Spätantike Paläste und Grossvillen im Donau - Balkan Raum, Akten des Internationalen Kolloquiums in Bruckneudorf vom 15. bis 18. Oktober 2008, Bonn, 219-231.

G. Kabakchieva, The Splendour of the Villa Armira, Plovdiv.

C. Marinescu, S. Cox, R. Wachter, "Walking and Talking Among Us: Personifications in a Group of Late Antique Mosaics”, CMGR IX, 2, Rome, 1269-1277.

J. Mladenova, "Les mosaïques de la villa d'Ivailovgrad (Bulgarie)”, CMGR III, Ravenna, 149-166.

J. Mladenova, The Ancient Villa Armira near Ivailovgrad, English summary of Bulgarian text, V. Volkov - G. Kabakchieva (eds.), Sofia, 191-194.

U. Pappalardo - R. Ciardiello, Mosaici greci e romani: Tappeti di pietra in età ellenistica e romana, Verona.

D. Parrish, "The Architectural Design and Interior Décor of Apartment I in Insula 2 at Ephesos", CMGR V, 2, Ann Arbor, MI, 143-158.

V. Popova, “The Mosaic Portraits of Villa Armira”, CMGR XII, Verona, 577-579.

M.-P. Raynaud - A. Islami, Corpus of the Mosaics of Albania 1. Butrint intramuros, Bordeaux.

J. Valeva, "La villa romaine Armira près d'Ivailovgrad (Bulgarie): Archives de Yanka Mladenova et nouvelles considérations", CMGR XII, Verona, 445-449.

M. Yacoub, Splendeurs des mosaïques de Tunisie, Tunis.

Zimmermann - Ladstätter 2011 N. Zimmermann - S. Ladstätter, Wall Painting in Ephesos from the Hellenistic to the Byzantine Period, İstanbul. 
